\title{
CHANGES OF THE MONITORING WINDFALLEN AREA ON THE BABIA GÓRA MOUNTAIN
}

\author{
Paweł Zadrożny' ${ }^{1}$, Joanna Krużel${ }^{2}$, Tomasz Lamorski ${ }^{3}$, Paweł Nicia' ${ }^{1}$ Piotr Kozina ${ }^{3}$ \\ 1 Department of Soil and Soil Protection, University of Agriculture in Kraków, al. Mickiewicza 21, 31-120 Kraków, \\ Poland, e-mail: rrzadroz@cyf-kr.edu.pl; rrnicia@cyf-kr.edu.pl \\ 2 Department of Ecology, Climatology and Air Protection, University of Agriculture in Kraków, al. Mickiewicza \\ 24/28, 30-059 Kraków, Poland, e-mail: joannakruzel90@gmail.com \\ 33 Babia Góra National Park, 34-223 Zawoja 1403, Poland, e-mail: tlamorski@bgpn.pl; piotrk@bgpn.pl
}

Received: 2016.10 .19

Accepted: 2016.11.16

Published: 2017.01.01

\begin{abstract}
The conducted research aimed at establishing the pace and range of the formation of spruce windfall in Compartment 93 of the Babia Góra National Park, where in 2005 by the decision of the Park's Director, with the approval of the Scientific Council of the Park, a monitoring area was created. During field work the range of the existing windfall area was mapped through determining its outermost points and their stabilization by means of the GPS. During the research an analysis of the aerial photographs made available by the Babia Góra National Park was carried out, in order to determine the changes in the range of the area deprived of trees. The analyzed photographs covered the area of 5 ha in Compartment 93 of the Park. The evaluation of changes in the tree layer was based on the graticule reproducing the $10 \times 10 \mathrm{~m}$ area of the real land. The "lack of trees" was stated when the areas were exposed in at least $75 \%$. The comparative analysis of the images from aerial photographs of Compartment 93 in 2003, 2011, 2012 and 2014 showed distinct changes in the range and size of the gaps made by fallen trees. The share of the gaps in the forest stand in the whole analyzed area increased from $2 \%$ in 2003 to over $52 \%$ in 2014 . Therefore, the progression of the size of the changes is considerable and the disintegration of the tree layer is growing, especially comparing the 2003-2011 and the twice shorter 2011-2014 periods. In the analyzed periods, the increase in the gap area was similar (ca. 26\%), yet the pace of the phenomenon was twice faster. The obtained results were an argument in favor of increasing the monitoring area from 0.28 ha to 1.55 ha.
\end{abstract}

Keywords: windfallen areas, strong winds, the Babia Góra mountain range

\section{INTRODUCTION}

In the past several decades a progressing climate warming has been observed, accompanied with an increase in extreme phenomena. The third and fourth IPCC reports confirm the increase in the number of meteorological phenomena of extreme nature in Europe [Miętus 2005, Grabowska et al. 2007, Wegrzyn 2008, Kundzewicz 2011]. In moderate latitudes one of them is strong winds [Dotzek 2003, Leckebusch and Ulbrich 2004], which, depending on their speed, manner and place of occurrence are called gales, whirlwinds, hurricanes or foehn/halny [Rojan 2010, Pawlik 2012b, 2015]. The occurrence of such violent phenomena poses serious hazards for forest stands, where falling trees lead to the formation of extensive areas covered with windfallen trees [Zachara 2006, Dąbrowska 2009, Pawlik 2012a, 2015, Dmytrenko et al. 2015]. In the mountains the areas most susceptible to this phenomenon are forest areas with dominant homogeneous ageand species-wise tree stands [Gądek 1987]. The ones considered most sensitive are coniferous species [Schaetzl et al. 1989, Philips et al. 2008], especially the spruce, whose shallow roots lead 
to its increased susceptibility to windfalls [Gądek 1987, Zachara 2006, Simon et al. 2011].

Fallen trees bring about significant changes in the functioning of a given section of the forest [Stephens 1956, Norman et al. 1995, Philips et al. 2008, Šamonil et al. 2010a, 2010b, Simon et al. 2011, Pawlik 2013]. When a tree falls down, it creates a gap in the forest canopy, providing more access to sunlight, wind and rainfall, which accelerates soil falling off the exposed roots. This leads to the forming of post-windfall microrelief made up of tree holes and roots which in time form a post-windfall knoll. The decomposing leaves, needles, bark, branches and the wood of the fallen tree enrich the soil surface with organic matter, which is favorable to the development of nitrophilic plants [Masalska 1997].

An important factor contributing to the falling of trees is their soil substrate. This phenomenon occurs most frequently on shallow, marshy or strongly skeletal soils [Stocki 2003]. Tree toppling, through uprooting, causes a local distortion of the soil profile, followed by shifting or blending of soil levels. This results in exposing lower, mineral soil levels, usually very poor in humus, or in the formation of places enriched with organic matter [Masalska 1997, Šamonil et al. 2010a, 2010b].

The post-windfall holes constitute characteristic microhabitats which can, depending on the size of the surface of the windfallen area, form a considerable part of the general habitat structure of the forest [Sokołowski 1934, Grodzki and Starzyk 2004, Šamonil et. al. 2010a, 2010b; Simon et al. 2011, Pawlik 2012]. The appearance of windfallen trees results in the changes in soil properties in this area and favors the forming of new microhabitats. The soil variability in such windfallen areas determines the formation of microhabitats which differ in the pace and range of plant colonization [Beatty and Stone 1986].

Due to its location, height and landform, the Babia Góra mountain range is exposed to violent meteorological phenomena connected with strong winds, including the very strong, blustery foehntype wind - the halny [Obrębska-Starkel 2004]. Among the many effects of this in the Babia Gora mountain range are the areas covered with windfallen and windsnapped trees, the occurrence of which has clearly increased in recent years, which is also connected with the age and species composition of the existing tree stands [Chochó 12008 ].

The aim of the research was to establish the pace and range of the windfallen spruce area in
Compartment 93 of the Babia Góra National Park (BGNP) in the past decade.

\section{MATERIALS AND METHODS}

The research was carried out in the windfallen spruce area formed in November 2004, whose area is growing due to the continual falling of trees. The area is situated on the south-eastern slope in the ecotone zone of the lower and upper sections of the Babia Góra mountain range (Compartment 93 of the BGNP, Fig. 1). In 2005 by the decision of the BGNP Director with the approval of the Scientific Council of the Park, a monitoring area was created there.

The research included field work and studies. During the field work the range of the existing windfall area was mapped through determining its outermost points and their stabilization by means of the GPS technology - in 2005 using GPSmap 60CSx (Garmin) and in 2015 using Spectra Precision (Ashtech) MobileMaper 10 with Esri ArcPad 10.0 R4. The obtained measurements were used to make maps of the range of the growing area in the Esri ArcMap 10.2.2. program (the license owned by the BGNP with the main office in Zawoja) (Figure 1).

Additionally, in 2005, in order to establish the range of the changes in the soil cover of the windfallen area, preliminary measurements were carried out of the elements of windfall microrelief. The measurements were made not only in the examined area but also in the adjacent windfall area formed at the same time.

The studies involved determining the changes in the range of the area deprived of the dense forest canopy as a result of successive tree falls. During the research an analysis was carried out of the aerial photographs made available by the Babia Góra National Park, from the Małopolska Province Marshal Office, the Province Centre for Geodetic and Cartographic Documentation (2003) and from the BGNP Territorial Information System (2011, 2012 and 2014). The analyzed photographs covered the area of 5 ha in Compartment 93 of the BGNP. The evaluation of the range was carried out by analyzing the photographs of that area as regarded the density of the forest canopy, based on the graticule reproducing the $10 \times 10 \mathrm{~m}$ area of the real land. The "lack of trees" was stated when the areas were exposed in at least $75 \%$. 


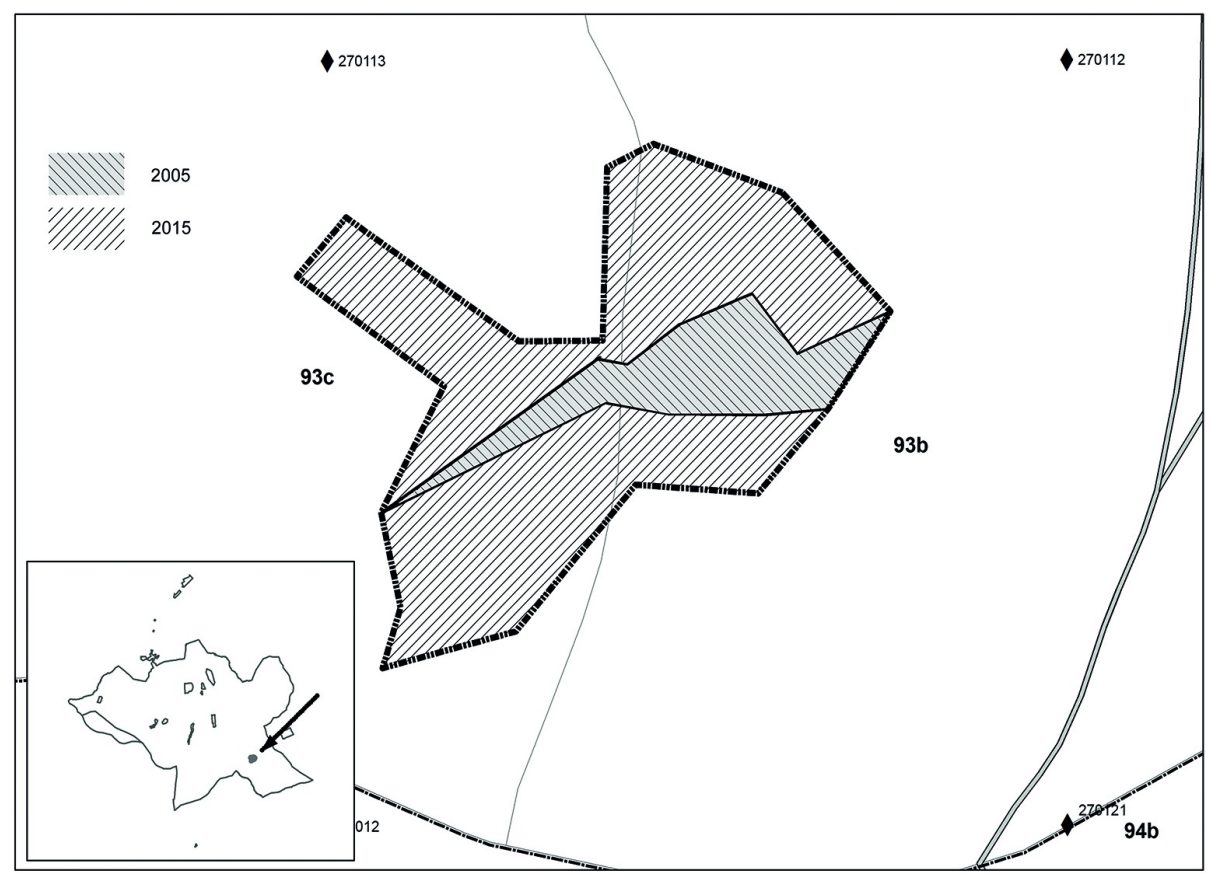

Figure 1. The monitored windfallen area in Compartment 93 of the Babia Góra National Park in 2005 and 2015 (made in ArcMap 10.2.2 software, license from BGNP)

\section{RESULTS AND DISCUSSION}

The post-windfall tree throws constitute characteristic microhabitats, which can, depending on the size of the windfallen area, be a significant part of the general forest structure. The inventory of the tree holes in two windfallen areas formed in November 2004 in Compartment 93 of the BGNP showed significant changes in the soil cover. In the first, 40-are area the tree holes occupied 5.09 ares and knolls 4.31 ares, which altogether was 9.40 ares, i. e. $23.5 \%$ of the whole windfallen area. In the second, 70-are area, the holes occupied 7.26 ares and knolls 5.34 ares, which altogether was 12.60 ares, i.e. $18.0 \%$ of the whole area.

The analysis of the available aerial photographs of the fragment of Compartment 93 from 2003 (Fig. 2), 2011 (Fig. 3), 2012 (Fig. 4) and 2014 (Fig. 5) showed distinct changes in the range and size of the gaps formed as a result of tree toppling.

The share of the area deprived of trees in the whole analyzed area increased from $2 \%$ in 2003 to over 52\% in 2014 (Fig. 6). The progression of the size of the changes is therefore significant, and the phenomenon of the tree stratum disintegration has been growing, especially when considering the periods: 2003-2011 and the twice shorter 2011-2014. In those periods the increase in the gapped area was similar (ca. 26\%), however the pace of the phenomenon was twice faster.
The violent hurricane-force winds which result in the appearance of large windfallen areas are a considerable hazard to the forests in Poland [Stocki 2003, Grodzki and Starzyk 2004, Zachara 2006, Dąbrowska 2009, Pawlik 2012b, Franczak 2013, Dmytrenko 2015]. The research carried out as part of the monitoring of the windfallen area in Compartment 93 of the BGNP confirmed a major influence of violent winds on the tree stands there. The windfallen areas formed as a result of the winds are continually growing on account of successive weather phenomena. The size and pace of those changes is varied, with a distinct upward trend in the past years. The increase in this phenomenon results in the growing interest of the local community [Franczak 2011-2012, Fujak 2011-2012]. It is a serious hazard for the Babia Góra forest stands dominated by the spruce. Tree toppling and dead wood lying on the ground may cause an increase in the number of forest pests and impact the potential hazard of gradations, whose presence contributes to the weakening of the still standing trees [Gądek 1987]. The infected and weakened trees are even more susceptible to falling. In consequence, the windfallen areas are growing larger and the natural conditions there are undergoing significant changes.

The characteristic microrelief formed as a result of the windfalls, with its distinct tree throws and torn out roots, considerably affects the prop- 


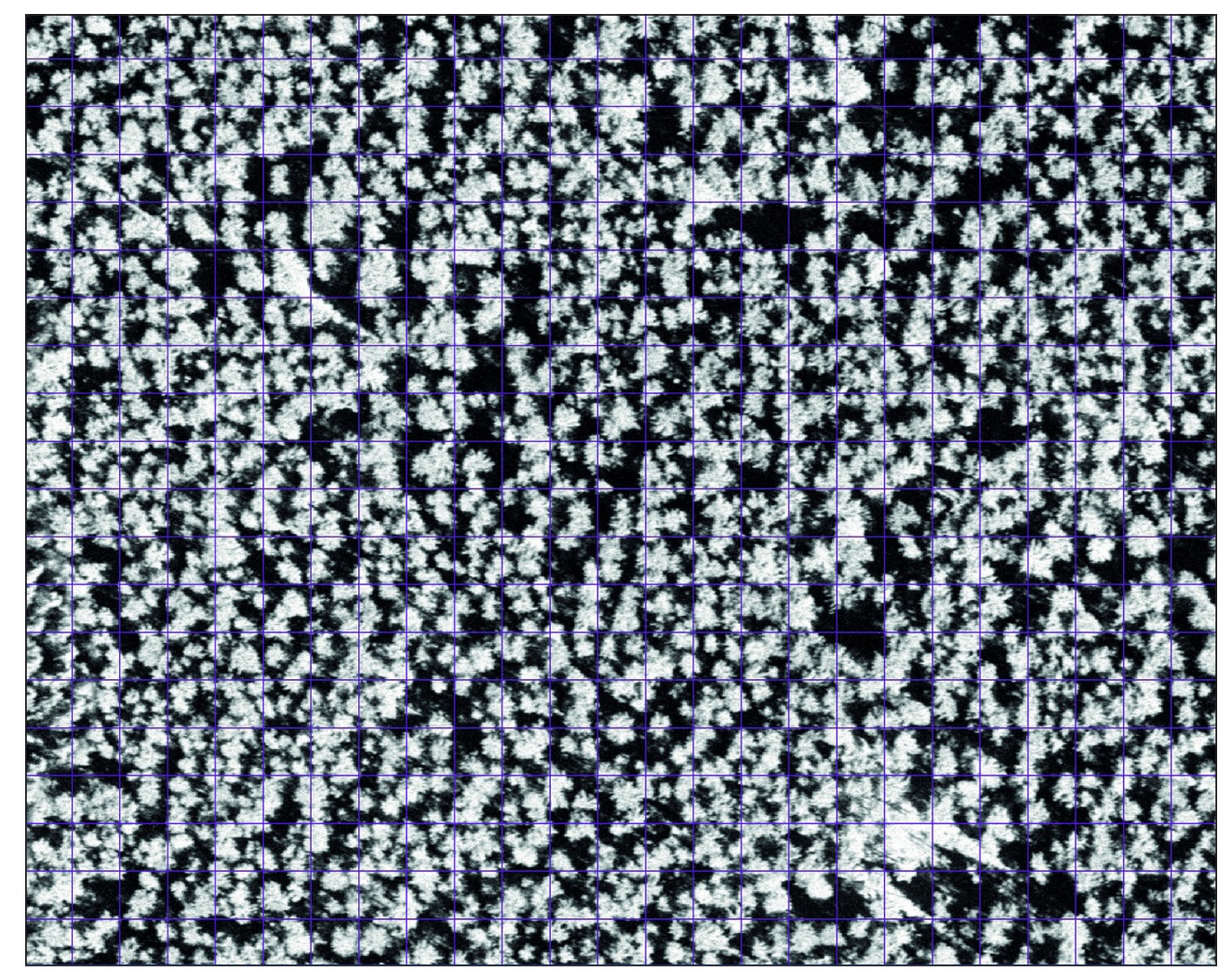

Figure 2. The analyzed area in Compartment 93 of the BGNP in 2003

(orthophotomap from 2003, made in ArcMap 10.2.2 software, license from BGNP)

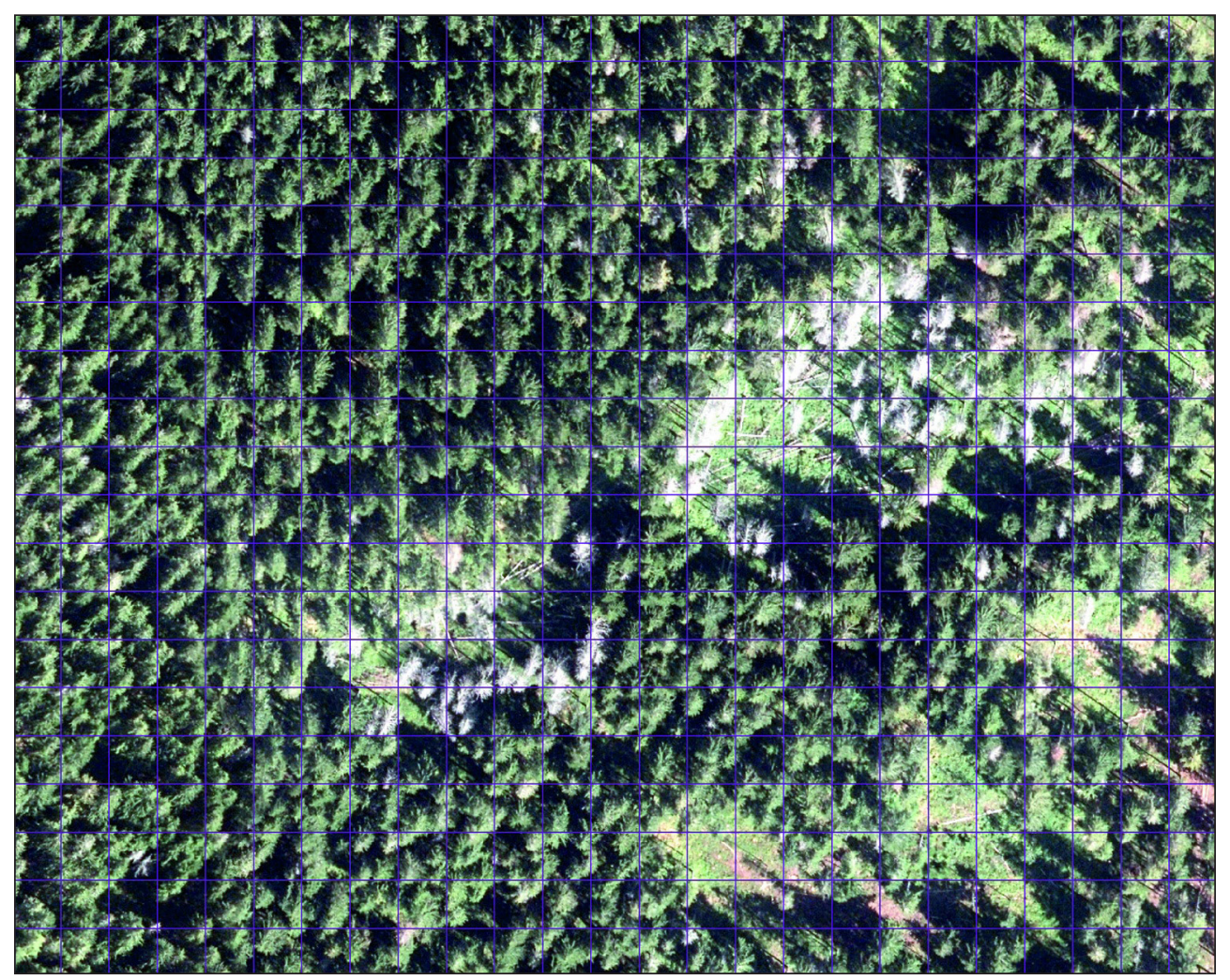

Figure 3. The analyzed area in Compartment 93 of the BGNP in 2011

(orthophotomap from 2011, made in ArcMap 10.2.2 software, license from BGNP) 


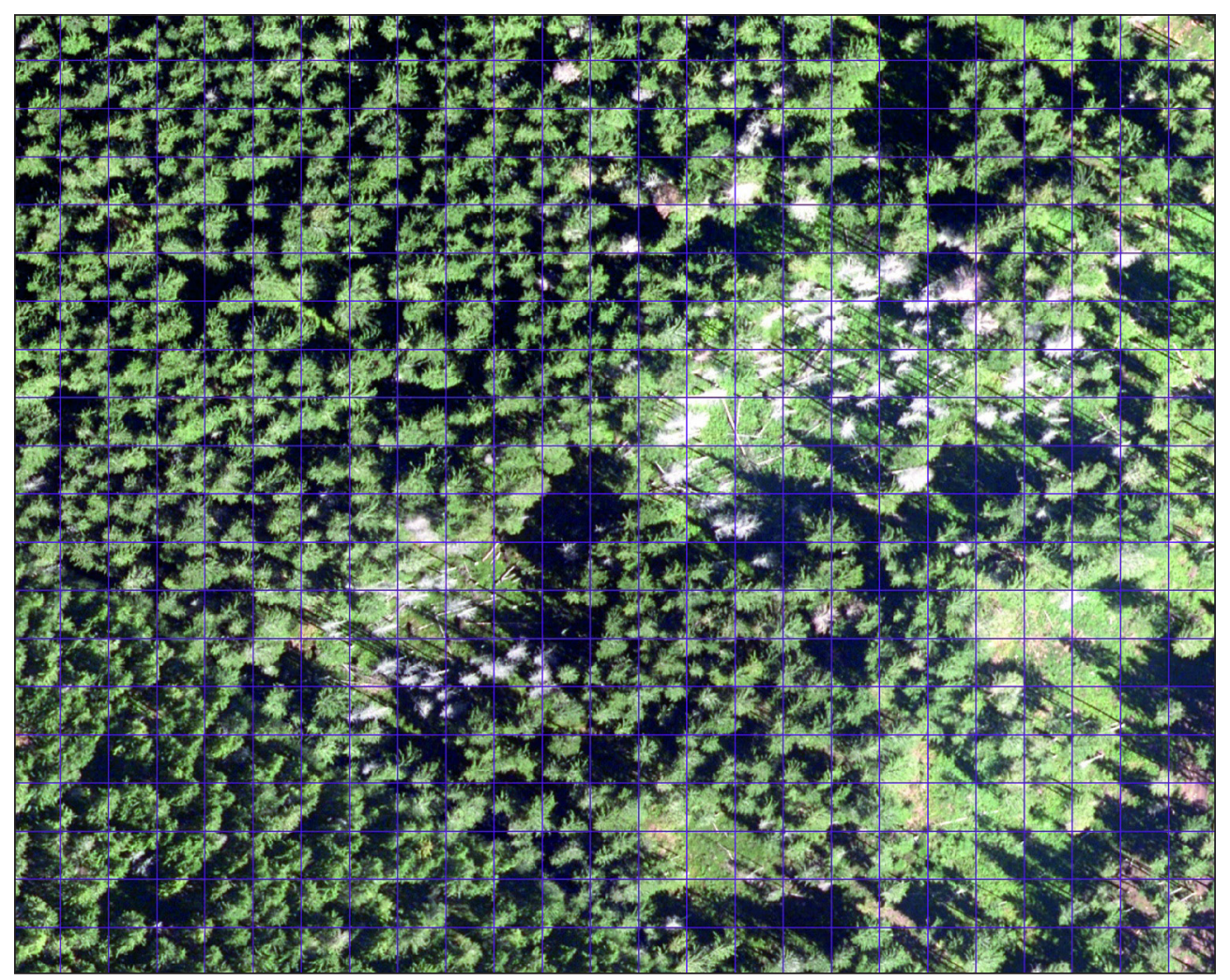

Figure 4. The analyzed area in Compartment 93 of the BGNP in 2012

(orthophotomap from 2012, made in ArcMap 10.2.2 software, license from BGNP)

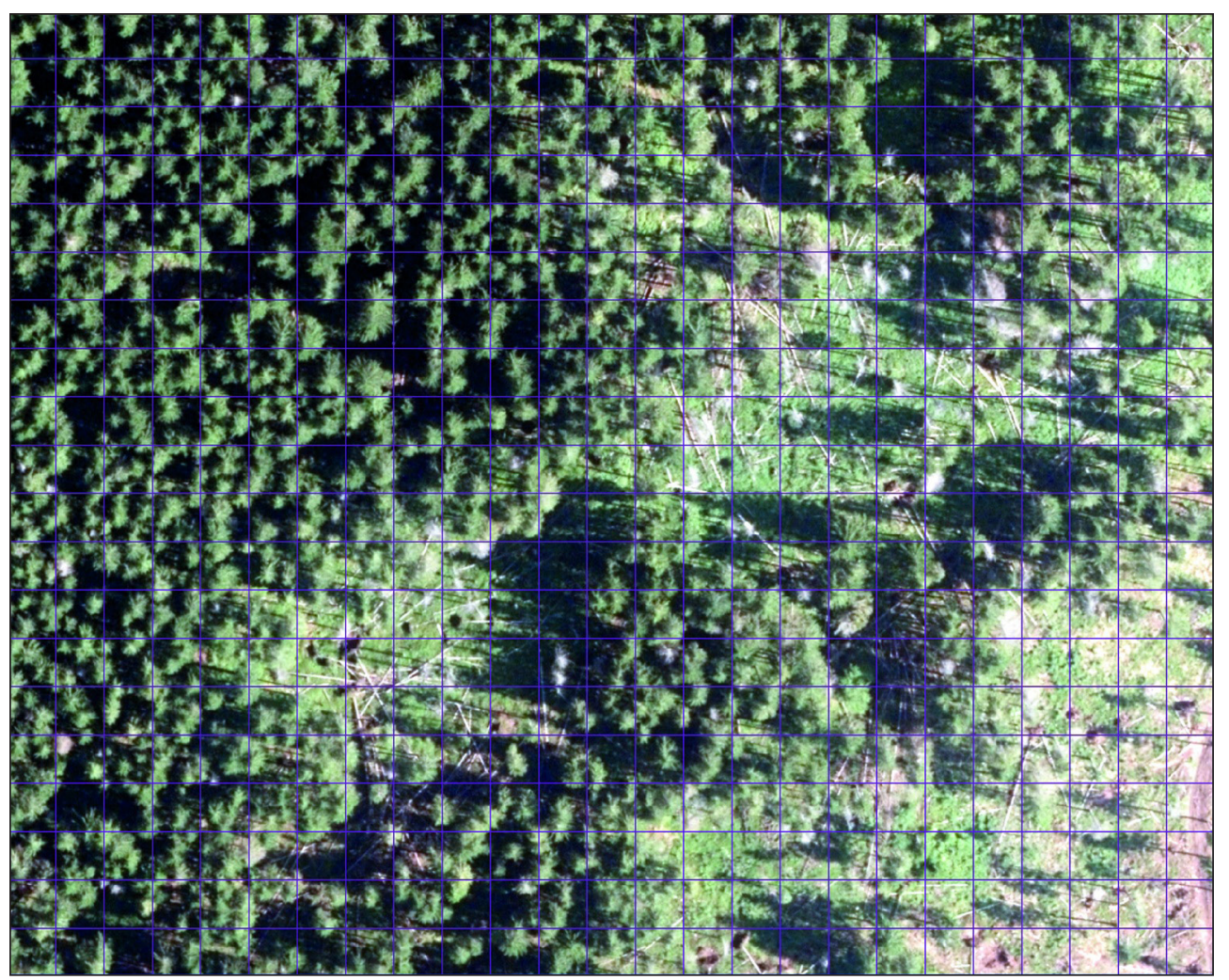

Figure 5. The analyzed area in Compartment 93 of the BGNP in 2014

(orthophotomap from 2014, made in ArcMap 10.2.2 software, license from BGNP) 


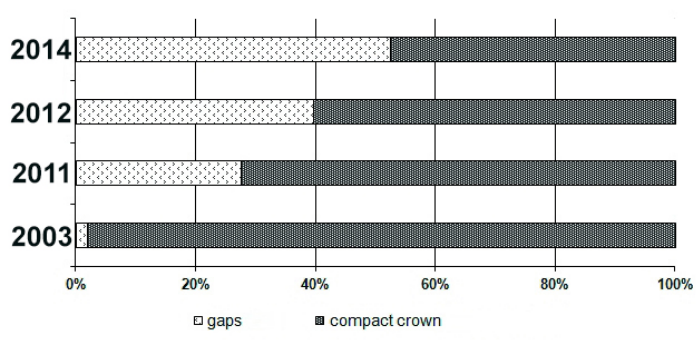

Figure 6. Changes in the gap size of the analyzed area in Compartment 93 of the BGNP in 2003-2014

erties of the soil cover of the windfallen area [Stephens 1956, Pawlik 2012a, Šamonil et al. 2010a]. The in parts exposed levels of the matrix, the mixed soil strata and the formed mounds of the soil material, create conditions for geomorphological and soil processes [Pawlik 2012a, 2013]. This leads to morphological and profile-related changes of the already shaped soils, which directly determines the habitat conditions and the composition of the occurring plants [Beaty and Stone 1986, Šamonil et al. 2010a, Pawlik 2012a]. The size and range of the changes caused by the formation of the pit-and-mound pair [Ulanowa 2000] may be very large; as stated by Gabet et al. [2003], even up to $40 \%$ of the windfallen area in the moderate climate zone forests.

As a result of the described changes, as motioned by the team of the authors of this work, by the decision of the BGNP Management, the size of the monitoring area established in 2005 in Compartment 93 was increased in 2015 from 0.28 ha to 1.55 ha. This will facilitate further large-scale interdisciplinary monitoring and comparative research concerned with the dynamics and range of the changes within the post-windfall microhabitats.

\section{CONCLUSIONS}

1. In the past 11 years the extent of the disintegration of the forest stand in the monitored area was very large - from 2\% in 2003 to $52 \%$ in 2014 .

2 . The pace of the forest stand disintegration in the monitored area in the past 4 years has been almost twice faster compared to the period 2003-2011.

3. The formation of a windfallen area plays a significant role in shaping the microrelief of the land and soil cover, particularly in mountainous areas.
4. The functioning of the monitoring area in Compartment 93 of the BGNP has a significant impact on the accuracy and precision of long-term observation of changes taking place in the formed windfallen area, not only within the tree stand itself but also other elements of the environment.

\section{Acknowledgements}

This research was financed by the Ministry of Science and Higher Education, Republic of Poland.

\section{REFERENCES}

1. Beatty S.W., Stone E.L. 1986. The variety of soil microsites created by tree falls. Can. J. For. Res., $16,539-548$.

2. Chochół D. 2008. Korniki na Babiej Górze. Tatry $3(25), 60$.

3. Dąbrowska K. 2009. The morphogenetic impact of the bora type wind (19th November 2004) on the relief of Danielov dom area (The High Tatras). Landform Analysis, 11, 5-10.

4. Dmytrenko E., Mionskowski M., Bruchwald A. 2015. Zagrożenie lasów Polski na podstawie modelu ryzyka uszkodzenia drzewostanu przez wiatr. Sylwan, 159(5), 361-371.

5. Dotzek N. 2003. An updated estimate of tornado occurrence in Europe. Atmospheric Research, 67-68, 153-161.

6. Holeksa J. 1998. Rozpad drzewostanu i odnowienie świerka a struktura i dynamika karpackiego boru górnoreglowego. Monografie Botaniczne, 82, 1-209.

7. Franczak P. 2011-2012. Wiatrołomy i wiatrowały na obszarze Podbabiogórza. Rocznik Babiogórski, $13,77-86$.

8. Franczak P. 2013. Wpływ silnego wiatru na zmianę krajobrazu i rzeźby terenu na przykładzie wiatrowałów z południowych stoków pasma Policy (Beskid Żywiecki). Zarządzanie Ochroną Przyrody w Lasach, 7, 273-285.

9. Franczak P. 2014. Ekstremalne zdarzenia meteorologiczne i hydrologiczne na obszarze Podbabiogórza i Żywiecczyzny w okresie od XVI do pierwszej dekady XXI wieku. Rocznik Babiogórski, 15, 83-96.

10. Fujak J.2011-2012. Wiatrołomy i wiatrowały-nowe układy w przyrodzie i ich znaczenie ekologiczne. Rocznik Babiogórski, 13, 87-92.

11. Grabowska K., Panfil M., Olba-Zięty E. 2007. Ekstremalne warunki termiczne w latach 1951-2005 
w Polsce południowo-wschodniej. Acta Agrophysica, 10(2), 341-347.

12. Grodzki W., Starzyk J.R. 2004. Wiatrołomy w wybranych parkach narodowych w Karpatach i wynikające $\mathrm{z}$ nich potrzeby badawcze w zakresie ochrony lasu. Leśne Pr. Bad., 3, 119-124.

13. Kundzewicz Z.W. 2011. Zmiany klimatu, ich przyczyny i skutki - obserwacje i projekcje. Landform Analysis, 15, 39-49.

14. Leckebusch G.C., Ulbrich U. 2004. On the relationship between cyclones and extreme windstorm events over Europe under climate change. Global and Planetary Change, 44, 181-193.

15. Masalska A. 1997. Zarastanie wykrotów świerkowych W zbiorowisku grądowym W Białowieskim Parku Narodowym. Manuskrypt pracy magisterskiej, Biblioteka Białowieskiej Stacji Geobotanicznej UW, Białowieża - Warszawa.

16. Miętus M. 2005. Ekstremalne zjawiska klimatyczne $\mathrm{z}$ perspektywy IPCC. Ekstremalne zjawiska hydrologiczne i meteorologiczne. PTGeof., IMGW, Ser. Monografie IMGW, 19-31.

17. Norman S.A., Schaetzl R.J., Small T.W. 1995. Effects of slope angle on mass movement by tree uprooting. Geomorphology, 14, 19-27.

18. Obrębska-Starkel B. 2004. Klimat Babiej Góry. W: B.W. Wołoszyn, A. Jaworski, J. Szwagrzyk (red.) Babiogórski Park Narodowy. Monografia przyrodnicza. Wyd. Komitet Ochrony Przyrody PAN, Babiogórski Park Narodowy. Kraków, 137-151.

19. Pawlik Ł. 2012a. Przekształcenia powierzchni stokowych w Sudetach w wyniku procesu saltacji wykrotowej. Landform Analysis, 20, 79-94.

20. Pawlik Ł. 2012b. Zniszczenia w lasach sudeckich pod wpływem orkanu Cyryl (18-19.01.2007 r.) - implikacje historyczne i regionalne. Przegląd Geograficzny, 84(1), 53-75.

21. Pawlik Ł. 2013. The role of trees in the geomorphic system of forested hillslopes - A review. Earth-Science Reviews, 126, 250-265.

22. Pawlik Ł. 2015. Wiatrowały i wiatrołomy w lasach Nadleśnictwa Wałbrzych w świetle analizy danych z SILP w środowisku GIS oraz ocean efektów powierzchniowych procesu saltacji wykrotowej w Górach Suchych, Sudety Środkowe. Landform Analysis, 28, 61-72.

23. Phillips J.D., Marion D.A., Turkington A.V. 2008. Pedologic and geomorphic impacts of a tornado blowdown event in a mixed pine-hardwood forest. Catena, 75, 278-287.

24. Rojan E. 2010. Rola bardzo silnego wiatru w przekształcaniu rzeźby terenu w piętrze leśnym gór, na przykładzie wiatrowału w słowackich Tatrach Wysokich. Czasopismo Geograficzne, 81(1-2), 103-123.

25. Šamonil P., Král K., Hort L. 2010a. The role of tree uprooting in soil formation: A critical literature review. Geoderma, 157, 65-79.

26. Šamonil P., Tejnecký V., Borúvka L., Šebková B., Janík D., Šebek O., 2010b. The role of tree uprooting in Cambisol development. Geoderma, 159, 83-98.

27. Schaetzl R.J., Burns S.F., Johnson D.L., Small T.W. 1989. Tree uprooting: review of impacts on forest ecology. Vegetatio, 79, 165-176.

28. Simon A., Gratzer G., Sieghardt M. 2011. The influence of windthrow microsites on tree regeneration and establishment in an old growth mountain forest. Forest Ecology and Management, 262, 1289-1297.

29. Sokołowski M. 1934. Szkody od powału w lasach tatrzańskich i sposoby zapobiegania im w zakresie hodowli lasu. Prace Rolniczo-Leśne 10, PAU, Kraków.

30. Stephens E.P. 1956. The uprooting of trees: a forest process. Soil Sci. Amer. Proceed., 20(1), 113-116.

31. Stocki J. 2003. Szkody od wiatrołomów i wiatrowałów w Lasach Państwowych w latach 1999-2002. Przemysł Drzewny, 54(6), 7-10.

32. Węgrzyn A. 2008. Typowe i anomalne długości okresu wegetacyjnego na lubelszczyźnie. Acta Agrophysica, 12(2), 561-573.

33. Zachara T. 2006. Problem szkód w lasach powodowanych przez śnieg i wiatr oraz sposoby przeciwdziałania im. Sylwan, 150(10), 56-64. 